\title{
Is It Still Profitable to Grow Lychee in Florida?1
}

\author{
Edward Evans, Robert Degner, Jonathan Crane, Ray Rafie, and Carlos Balerdi ${ }^{2}$
}

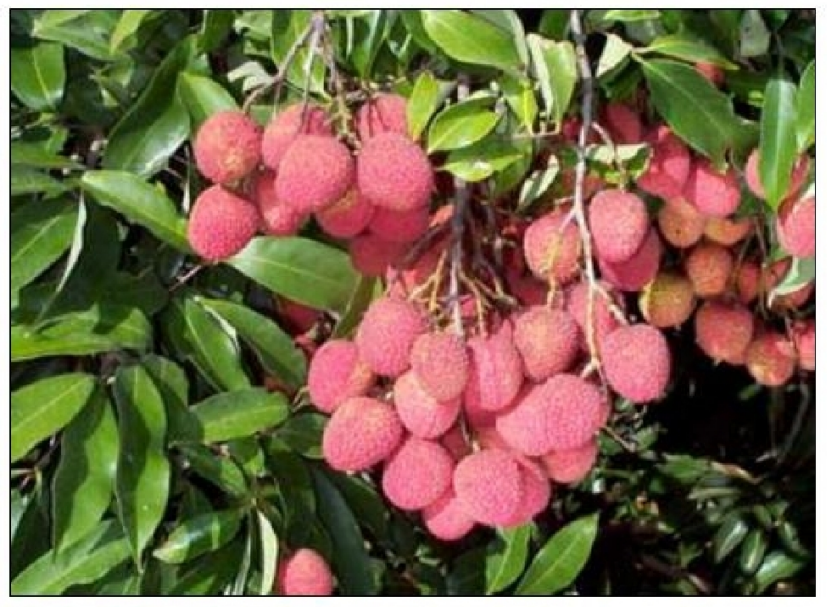

Introduction

The top five world lychee producing countries are China, India, Taiwan, Thailand, and Vietnam. Lychee is also grown commercially in many other subtropical areas, including Israel, Australia, Madagascar, parts of Africa, and at higher elevations in Mexico and Central and South America. A relatively small amount is produced in the United States (FAO, 2002).
World production of lychee is estimated to be around 2.11 million tons, with more than $95 \%$ of the world cultivation occurring in Asia. Total production in the Southern Hemisphere (mainly Africa, Madagascar, and Australia) is about 50,000 tons. The production season in the Northern Hemisphere extends from about April to mid-August, and in the Southern Hemisphere from November to February.

In the United States, commercial production of lychee takes place in Florida, Hawaii, and California. Florida is the largest U.S. producer (1,200 acres) of lychee, followed by Hawaii (300 acres) and California (60 acres). Total annual production of lychee fruit in the United States is estimated at 433 tons, which is considered minuscule compared to world production.

Production of lychee in Florida expanded rapidly in the 1990s following Hurricane Andrew in 1992. From about 200 acres pre-hurricane, acreages increased to slightly over 500 acres by 1996 and to the current level by 2000 (Degner, Stevens, and Morgan, 2002). Growers were drawn to the high returns and the prospects driven by strong demand from an increasing U.S. Asian population. However,

1. This is EDIS document FE496, a publication of the Department of Food and Resource Economics, Florida Cooperative Extension Service, Institute of Food and Agricultural Sciences, University of Florida, Gainesville, FL. Published November 2004. Please visit the EDIS website at http://edis.ifas.ufl.edu. 2. Edward Evans, Assistant Professor, Department of Food and Resource Economics, Tropical Research and Education Center, Homestead, FL; Robert Degner, Professor and Director of Florida Agricultural Market Research Center, Department of Food and Resource Economics, University of Florida, Gainesville, FL; Jonathan Crane, Professor, Department of Horticultural Sciences, Tropical Research and Education Center, Homestead, FL; Ray Rafie, Extension Agent, Miami-Dade County South Extension Office, Homestead, FL; and Carlos Balerdi, Extension Agent, Miami-Dade County South Extension Office, Homestead, FL, Florida Cooperative Extension Service, Institute of Food and Agricultural Sciences, University of Florida, Gainesville, FL.

The Institute of Food and Agricultural Sciences is an equal opportunity/affirmative action employer authorized to provide research, educational information and other services only to individuals and institutions that function without regard to race, color, sex, age, handicap, or national origin. For information on obtaining other extension publications, contact your county Cooperative Extension Service office. Florida Cooperative Extension Service/Institute of Food and Agricultural Sciences/University of Florida/Christine Taylor Waddill, Dean. 
with the current prices plummeting well below those obtained three to five years ago and with costs of production continually rising, many growers are questioning if it still makes sense to grow lychee. In the following analysis, we examine developments within the U.S. lychee industry and focus on the costs and returns of producing lychee in Florida to determine whether farmers can still make a profit from growing this commodity.

\section{Demand for Lychee}

The demand for fresh lychee in the United States has increased considerably within recent years. This has been due in part to increases in Asian ethnic populations in the United States and to health-conscious consumers who purchase fruit in specialty stores (Figure 1). In the past, the demand was mainly for the frozen and canned fruit, but the demand for the fresh fruit has increased substantially. The main lychee suppliers to the United States are Taiwan, Mexico, China, and Israel. In recent years, lychee production in the United States has been facing heavy competition. Between 1998 and 2003, lychee imports grew from 967.9 tons to $3,345.8$ tons, with the bulk of the increase in imports from Taiwan. In 2002, Taiwan doubled its exports to the United States, and has now overtaken Mexico as the main supplier to the U.S. market. In 2003, Taiwan increased its lychee exports to an all-time high of 2,373 tons, or $70 \%$ of total U.S. imports of lychee (which has caused the U.S. domestic price for lychee to plunge to new levels).

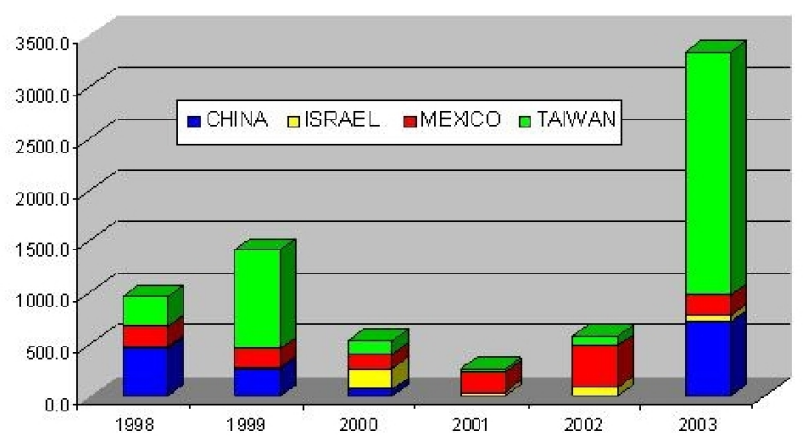

Figure 1. U.S. imports of lychee, 1998-2003 (tons).

\section{Farm Gate Prices}

Apart from a slight recovery in 2002, farm gate prices trended steadily downwards over the period 1998-2003 (Figure 2). From a high of $\$ 5.10$ per pound received by the growers in 1998, prices fell to approximately $\$ 1.10$ in 2003 , or by $78.7 \%$.

The biggest decline in prices was recorded in 2003 , with growers receiving a price that was only $33.4 \%$ of the price received in the previous year, and $36.4 \%$ of the previous five-year average price of $\$ 2.96$ per pound. For the first time, farmers had to apply for trade adjustment assistance, also known as TAA (the Trade Act of 2002 established the Trade Adjustment Assistance for farmers, which provides technical assistance and cash benefits to eligible farmers and fishermen from the United States Department of Agriculture). As noted earlier, the sharp decline in price in the marketplace has been attributed to the surge of lychee imports from Taiwan and to a lesser extent from Mexico. Although imports from Taiwan should stabilize at current levels, U.S. domestic farm gate prices are expected to remain weak in the foreseeable future due to the prospect of China re-entering the U.S. market.

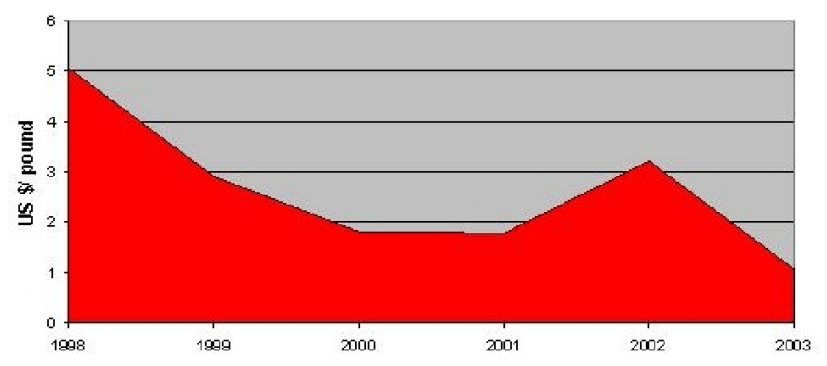

Figure 2. U.S. domestic farm gate prices for lychee, 1998-2003.

\section{Cost of Production}

Table 1 illustrates a sample budget based on a five-year average yield of 5,000 pounds of lychee per acre (assuming a pack-out rate of 70\%) and on estimates of the current average F.O.B. price in South Florida. It should be pointed out that yields and costs for individual operations can vary widely. For instance, lychee yields have been known to range from a low of 600 pounds per acre in a bad year to a high of 10,000 pounds per acre in a good year. 
Additional assumptions include charges of 50 cents per pound for picking, hauling, and packing. Packers are assumed to assess a sales charge of $10 \%$ of the F.O.B (free on board) sales price.

Table 1 also reveals an average per acre total cost of production and marketing of $\$ 6,385$ and gross revenue of $\$ 8,750$, giving a net return of $\$ 2,365$. This represents a $37 \%$ return on investments and recurring costs. Total pre-harvest costs are estimated at $\$ 3,010$ per acre (about $\$ 0.60$ per pound) while total harvest and marketing costs amount to $\$ 3,375$ per acre (roughly $\$ 0.68$ per pound). From Table 1 , it is apparent that the greatest costs are harvesting and marketing, accounting for as much as $52 \%$ of the total costs of production. Reducing these costs would contribute to improving the returns.

In addition to reducing production costs to improve profitability, improving fruit quality could influence market prices. Returns can be vastly improved by increasing yields per acre (discussed later). Table 2 shows the estimated net returns for various price and yield combinations in South Florida. The yields chosen reflect expected average yields in low, medium, and high years, while prices reflect the range paid in recent years. Table 2 reveals that with a yield of 3,000 pounds or less, the grower would operate at a loss if the F.O.B. price were $\$ 1.50$. However, if the F.O.B. price were to increase from $\$ 1.50$ to $\$ 2$, net returns would improve considerably even if yields remained at this level. In situations where yields are high (7,000 pounds per acre) and price is close to the $\$ 2$ per pound level, growers could achieve net returns in excess of $\$ 6,000$. As Table 2 indicates, returns to lychee can vary considerably, depending on the type of year and the price received. It also shows quite clearly that a relatively small increase (decrease) in the market price tends to have much more impact on net return than would a similar increase (decrease) in yield. For example, increasing the price from $\$ 1.50$ to $\$ 2.00$ at 5,000 pounds per acre (33.3\% increase) causes the net profit to increase by $\$ 2,250$, whereas increasing yields from 5,000 to 7,000 pounds per acre (40\% increase) results in the net profit increasing by $\$ 1,700$ (from $\$ 1,240$ to $\$ 2,940)$. Notwithstanding, realizing such improvements through cost reductions would be extremely difficult.

\section{Conclusions}

Our analysis shows that with a yield of 5,000 pounds per acre and a F.O. B. price of $\$ 1.75$, it is possible to realize a net return of $\$ 2,365$ per acre, or returns to investment and recurring costs of $37 \%$. On the surface, such returns appear fairly attractive. However, when one considers that the present value of a string of such returns over a 20-year horizon (assuming a constant interest rate of $6 \%$ per annum) amounts to only about $\$ 27,000$ as opposed to the current market value of $\$ 55,000$ per acre for agricultural land in the area, one can understand why many growers are beginning to question the profitability of this enterprise. Viewed from a slightly different perspective, a grower taking out a loan today (assuming an interest rate of $6 \%$ and a payback period of 20 years) to purchase an acre of land for the purpose of growing lychee would be required to pay $\$ 4,795$ per annum over the next 20 years. This payback amount would far exceed the $\$ 2,365$ net returns $[\$ 2,815$ if rent is added back $(\$ 2,365+\$ 450$ $=\$ 2,815)]$. Moreover such calculations do not make allowances for establishment costs and the early years when the trees are not bearing. Hence, such an investment could only be justified on the grounds of speculation on land prices.

Our analysis also shows that the net returns to growers are more sensitive to changes in market prices and yields, and less so to efforts to reduce the cost of production.

\section{References}

Degner, R.L., T.J. Stevens, III, and K.L. Morgan. 2002. Miami-Dade County Agricultural Land Retention Study. Florida Agricultural Market Research Center, Department of Food and Resource Economics, University of Florida, Gainesville, FL. http://www.agmarketing.ifas.ufl.edu.

FAO. 2002. Lychee Production in the Asian-Pacific Region. Bangkok, Thailand: RAP Publications. 
Table 1. Estimated costs and returns for lychee in Miami-Dade County, FL, 2004.

\begin{tabular}{|c|c|c|}
\hline Category & (\$)/Acre/Year & (\$)/Pound \\
\hline \multicolumn{3}{|l|}{ Marketable Yield (5,000 pounds per acre) } \\
\hline F.O.B. Price in South Florida & & 1.75 \\
\hline TOTAL REVENUE & 8,750 & \\
\hline Operating Costs & 1,041 & \\
\hline Fertilizer & 429 & \\
\hline Fungicide & 260 & \\
\hline Herbicide & 85 & \\
\hline Insecticide & 117 & \\
\hline Interest on Operating Capital & 150 & \\
\hline Miscellaneous & 689 & \\
\hline Tree Removal and Site Preparation & 8 & \\
\hline Tree Replacement & 14 & \\
\hline Top, Head, and Prune Trees & 219 & \\
\hline Set Trees & 4 & \\
\hline Irrigation & 135 & \\
\hline Mow Middles & 80 & \\
\hline Gove Work and Hand Labor & 229 & \\
\hline Fixed Costs & 1,280 & \\
\hline Land Rent* & 450 & \\
\hline Supervision & 176 & \\
\hline Overhead & 304 & \\
\hline Equipment Repairs, Depreciation & 350 & \\
\hline TOTAL PRE-HARVEST COSTS & 3,010 & 0.60 \\
\hline Harvest and Marketing Costs & 3,375 & \\
\hline Pick, Haul, and Pack (\$0.50/pound) & 2,500 & 0.50 \\
\hline Sales Charge (@ 10\% of \$1.75 F.O.B.) & 875 & 0.18 \\
\hline TOTAL COSTS & 6,385 & 1.28 \\
\hline NET RETURNS (Total Revenue minus Total Costs) & 2,365 & 0.47 \\
\hline
\end{tabular}


Table 2. Lychee estimated net returns for various price and yield combinations, South Florida, 2004.

\begin{tabular}{|cccc|}
\hline \hline & \multicolumn{3}{l|}{ F.O.B. Price, Homestead (dollars per pound) } \\
\hline & $\$ .150$ & $\$ 1.75$ & $\$ 2.00$ \\
\hline Yield (pounds per acre) & \multicolumn{3}{c}{ Returns Per Acre (dollars) } \\
\hline 3,000 & & & 890 \\
5,000 & -460 & 215 & 3,490 \\
7,000 & 1,240 & 2,365 & 6,090 \\
\hline \hline
\end{tabular}

